\begin{abstract}
Maja Čavić
Associate Professor

University of Novi Sad

Faculty of Technical Sciences

Serbia

Marko Penčić

Research Associate University of Novi Sad Faculty of Technical Sciences Serbia

Milan Rackov

Assistant Professor University of Novi Sad Faculty of Technical Sciences

Serbia

Jovan Dorić

Associate Professor University of Novi Sad Faculty of Technical Sciences

Serbia

Zhenli Lu

\section{Graphical Synthesis of 6-bar Dwell Linkage Mechanism}

Mechanisms of machines completing a repeating operation have many applications in the processing industry. During the working cycle, the output link of the mechanism has one or more periods of dwell, while the input link moves continuously. The paper presents the graphical synthesis of 6-bar linkage mechanism with high class structure groups. The procedure is based on the synthesis at the extreme positions of the mechanism, simplifying the task to a problem with a finite number of precise positions. At the core of this procedure are simple, easily visible and understandable geometric constructions that are then used to form equations suitable for further analysis and optimization. Motion of the mechanism resulting from the synthesis has some inaccuracy - the output link moves during the dwell phase, completing an angle of $\pm 0.5^{\circ}$, which is considered accurate enough for a wide range of practical applications.
\end{abstract}

Full Professor Changshu Institute of Technology School of Electrical Engineering and Automation
Keywords: graphical synthesis, 6-bar linkage mechanism, dwell linkage mechanism, high class kinematic group

\section{INTRODUCTION}

Machines that complete a repeating operation are widely used in the food, printing, textile and automotive industry [1-3]. The working elements of the machine are connected to the output link of the working mechanism, with its motion depending on the technological operation being performed by the machine. The law of motion of the output link during one operation represents the working cycle. In some cases, the output link is required to have periods of dwell during the cycle, while the input link, usually connected to the driving motor, remains in motion. The motion law of working link in the beat-up mechanism must have dwell periods in order to realize the correct condition for weft insertion [4]. Performance of internal combustion engine can be significantly improved by manipulating its dynamics at the top dead center position [5] and one possible way is to use piston motion law with dwell [6]. There are many mechanisms in existence that fulfil these requirements, the most well-known being cam and Geneva mechanisms $[7,8]$. A law of motion of the output link that contains periods of dwell can also be realized with 6-bar linkage mechanism. Linkage mechanisms can achieve only an approximation of stillness during periods of dwell. However, it is possible, through synthesis, to obtain mechanisms where the inaccuracy of the stillness is small enough to be considered nonexistent, justifying the use of linkage mechanisms in working cycles with periods of dwell $[9,10]$.

Received: June 2018, Accepted: December 2018.

Correspondence to: Marko Penčić

Faculty of Technical Sciences,

Trg Dositeja Obradovića 6, 21000 Novi Sad, Serbia

E-mail: mpencic@uns.ac.rs

doi:10.5937/fmet1902226C

(C) Faculty of Mechanical Engineering, Belgrade. All rights reserved
In this paper, we present a procedure of the graphic synthesis of complex structure mechanisms containing high class structural groups.

\section{STATE OF THE ART}

Synthesis procedures are well developed for planar linkage mechanisms with a simple structure - both those with an open kinematic chain structure and those with a close one, though for the latter ones only for mechanisms with a lower number of links $[11,12]$. These types of mechanisms can not always fulfil the prescribed requirements - for example, a requirement for periods of dwell of the output link. Due to this, it becomes necessary to use mechanisms with more complex structure. First rational choice are 6-bar linkage mechanisms. Synthesis of a Stephenson III mechanism used in a press as a path generator is presented in [13]. The problem of generating a path for a Watt I mechanism used in a weaving machine is solved in [14]. The synthesis of Stephenson II mechanism as the function generator in 11 precise points is explored in [15].

There are a few possible approaches to the synthesis of 6-bar mechanisms with intermittent motion of the output link. The first approach consists of the synthesis of a 4-bar linkage where a point on the floating link follows either an arc or a straight line. Following this is the synthesis of an appropriate dyad connected to the 4bar linkage in the previously considered point. A procedure using nonlinear programming was used in [16] to synthesize the sixth link as a slider and a law of motion with one or two periods of dwell was obtained; [17] and [18] have a similar approach, with the RR dyad synthesized by kinematic geometry methods using Burmester points. The previously procedures all follow the trajectory of the floating link point during the whole 
cycle, even though only a part of it has significance. Due to this, some authors are attempting to develop different approaches to the formulation of the problem of synthesis. In [19], the condition is derived for the instantaneous dwell of output link, and then formed a function intended to fulfil that condition on a finite interval of the motion of the input link. Oscillating output link of 6-bar mechanisms achieve so-called extreme positions in which it changes direction of motion and its velocity is equal to zero [20]. Synthesis of a mechanism in extreme positions is shown in [21]. The initial 6-bar mechanism is divided into two 4-bar mechanisms with an oscillating output link. The equations for precise points are then formed and dimensions of the mechanism are obtained.

Based on the analysis of available sources, it can be seen that synthesis of dwell mechanisms is done predominantly using analytical methods. The advantages of analytical methods are precision and fast execution. However, the synthesis of 6-bar mechanisms is problematic, due to the existence of multiple solutions and singular positions, which complicate the solution procedure. Graphical methods make the physical meaning of the problem clearly visible - the shape of the mechanism can be seen, removing the issue of singularities and multiple solutions. Due to this, graphical methods are very convenient for solving specific practical problems.

(a)

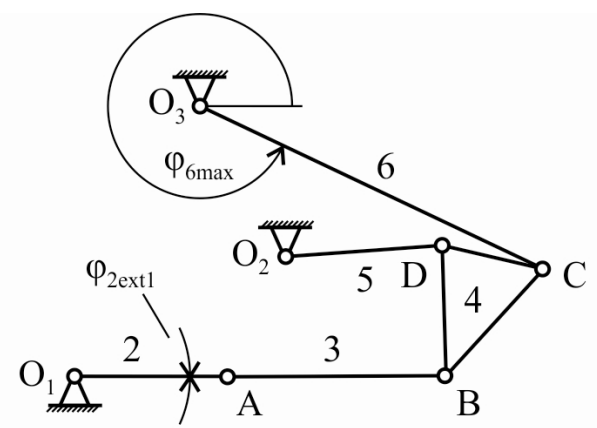

(b)

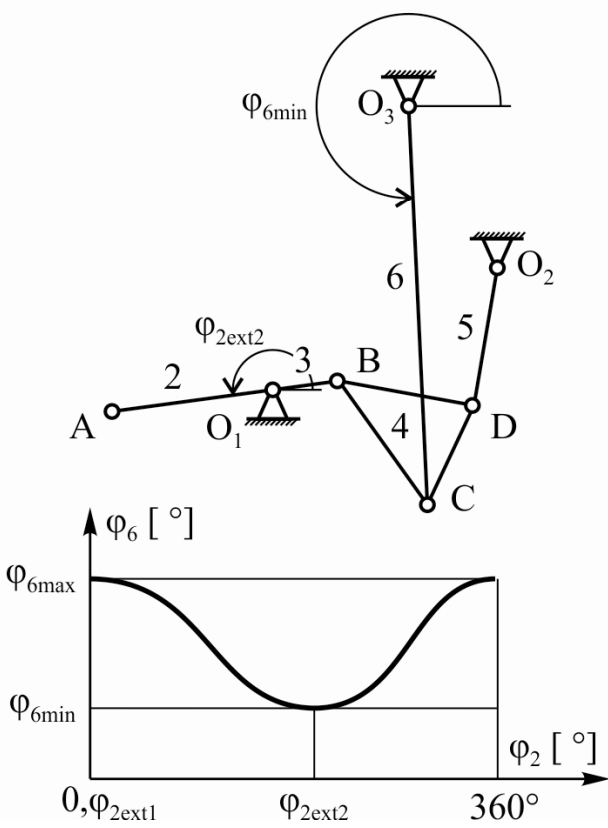

(c)

Figure 1. Six-bar Stephenson type mechanism with high class structural group: (a) mechanism in the right extreme position, (b) mechanism in the left extreme position and (c) the work cycle of the mechanism

\section{DWELL MECHANISM - EXTREME POSITIONS AND WORKING CYCLE}

Figures $1 \mathrm{a}$ and $2 \mathrm{~b}$ show the general case of a 6-bar Stephenson III mechanism with a high class structural group - a 4-bar Assur group consisting of links 3,4,5,6. The input link is link 2, and the output link is link 6 . The mechanism is shown in its extreme positions. In these positions, output link 6 changes its motion direction and angle $\varphi_{6}$ reaches its maximal and minimal value. The working cycle presented by the change of the output link 6 angle, with respect to the change of the input link 2 angle, is shown on Fig 1c. Generally, the output link has only instantaneous dwell in the extreme positions. According to [20], the extreme positions of the Stephenson III mechanism are achieved when angles of links 2 and 3 are the same or differ by exactly $180^{\circ}$.

Our goal is to design a 6-bar mechanism with an output link that will achieve dwell. This means that the working cycle should be as shown on Fig. 2.

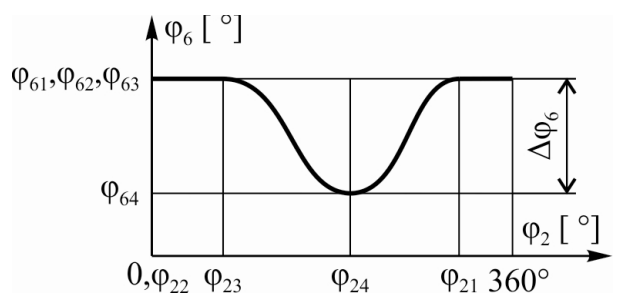

Figure 2. Working cycle of a mechanism with dwell of the output link: $\varphi_{22}, \varphi_{24}$ - position angles of the input link in the extreme positions of the mechanism, $\varphi_{21}-$ the angle when the output link enters dwell, $\varphi_{23}-$ the angle when the output link exits dwell, and $\varphi_{62}-\varphi_{64}=\Delta \varphi_{6}-$ interval of motion of the output link - stroke of the output link

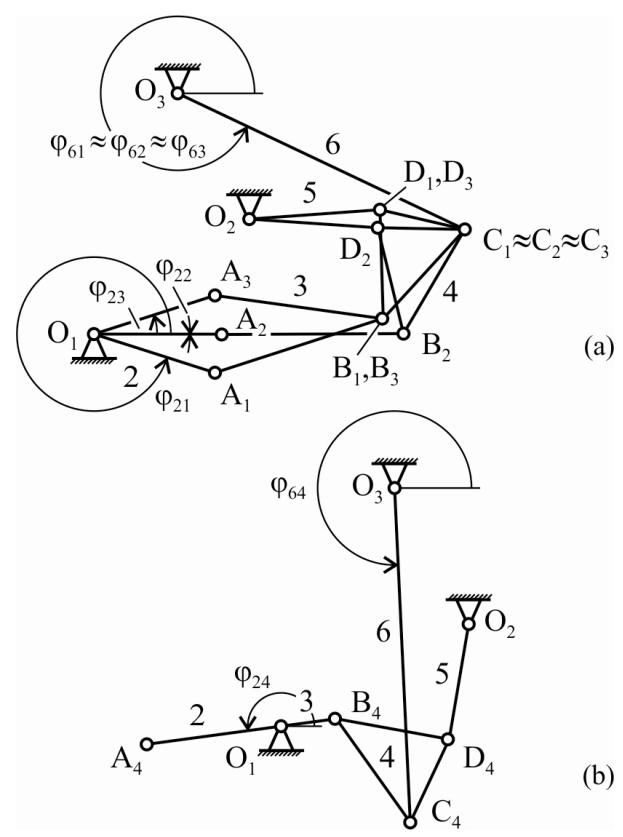

Figure 3. Mechanism during dwell period (a) and in the left extreme position (b)

The dwell of output link 6 lasts during the motion of input link 2 from position 1, through the right extreme position 2 and to position 3. Linkage mechanisms can not achieve absolute dwell, so the dwell of link 6 is approximate - motion of link 6 does exist, and it should be as small as possible. The smaller the oscillations of 
angle $\varphi_{6}$, the higher the quality of the solution. During period of dwell, links $3,4,5$ have small changes in position - Fig. 3a. The mechanism in the left extreme position is shown in Fig. $3 b$.

\section{SYNTHESIS PROCEDURE}

In accordance with [22], a synthesis procedure consisting of four steps is proposed. Step one - the mechanism is divided into mutually independent closed contours by way of graph theory. Step two - each contour is then divided into modules in accordance with the prescribed task of the synthesis. Since the metho-dology of open kinematic chain synthesis is well developed, they will be used as modules in the synthesis of complex mechanisms. A 2-bar open kinematic chain - dyad, in synthesis represents two bodies with two connections, where the final point is not connection, but a point of interest. Keeping in mind that two types of connections are used in planar mechanisms - rotational joints (R) and translational (sliding) joints $(\mathrm{T})$, it is theoretically possible to form the following modules: RR, TR, RT, and TT dyads. It can similarly be concluded that the following tryads can be formed: RRR, TRR, RTR, RRT, TTR, TRT, RTT and TTT [23], [24]. Step three - the solving order of the contours and modules is determined in accordance with their solvability and prescribed synthesis task. Step four - the modules are solved individually, and by combining them the final solution of the entire mechanism is reached.

Figure 4 shows a 6-bar mechanism with its independent contours: $\mathrm{O}_{1} \mathrm{ABCO}_{3} \mathrm{O}_{1}-$ contour 1 and $\mathrm{O}_{1} \mathrm{AB}$ $\mathrm{CDO}_{2} \mathrm{O}_{1}-$ contour 2 , and modules: RRR tryad $\mathrm{O}_{1} \mathrm{ABC}$ - module 1 , link $\mathrm{O}_{3} \mathrm{C}$ - module 2 and $\mathrm{RR}$ dyad $\mathrm{O}_{3} \mathrm{DC}-$ module 3 .

\subsection{Module 1 - RRR tryad $O_{1} A B C$}

During dwell of the output link, the mechanism passes through three precise positions 1,2,3. The input link has positions determined by angles $\varphi_{21}, \varphi_{22}, \varphi_{23}$. Since point $C$ is considered to be fixed, the RRR tryad can be viewed as a 4-bar linkage. Output link 4 rotates from position 1 by angle $\varphi_{412}$ to position 2 , and then by angle $-\varphi_{412}$ to position 3 , meaning that the total rotation angle from position 1 to position 3 equals zero - Fig. 5. To synthesize a 4-bar linkage as a function generator $\varphi_{4}\left(\varphi_{2}\right)$, it is necessary to define six parameters. First of all, angle $\varphi_{412}$, since only then does the synthesis task make sense. The remaining three can be many different design parameters. However, since point $\mathrm{C}$ represents a point of interest - the position of a tool, of the piston etc., the coordinates of point $\mathrm{C}\left(\mathrm{x}_{\mathrm{C}}, \mathrm{y}_{\mathrm{C}}\right)$ are adopted as a known parameters. Due to design requirements, the coordinates of point $\mathrm{O}_{1}\left(\mathrm{x}_{\mathrm{O} 1}, \mathrm{y}_{\mathrm{O} 1}\right)$ and the length of input link $\mathrm{O}_{1} \mathrm{~A}$ are adopted as the final three known parameters.

The synthesis procedure is based on kinematic inversion, and is shown in Fig. 5. Based on the known position of point $\mathrm{O}_{1}$, the length of input link $\mathrm{O}_{1} \mathrm{~A}$ and angles $\varphi_{21}, \varphi_{22}, \varphi_{23}$, the positions of link 2 are drawn. Then point $\mathrm{C}$ is added and connected with point $\mathrm{A}_{3}$. Link $\mathrm{CA}_{3}$ is rotated about point $\mathrm{C}$ for angle $-\varphi_{413}$, revealing point $A_{31}$. Due to the fact that angle $\varphi_{413}=0$, points $A_{3}$ and $A_{31}$ coincide. Then points $A_{31}$ and $A_{1}$ are connected, and a symmetry line is constructed on line $\mathrm{A}_{31} \mathrm{~A}_{1}$.

(a)

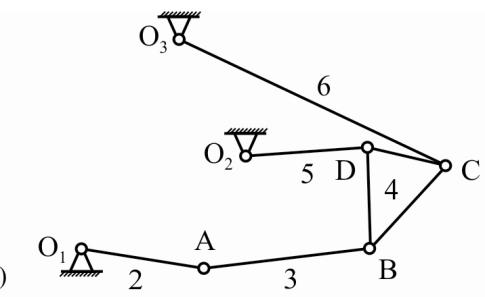

(b)

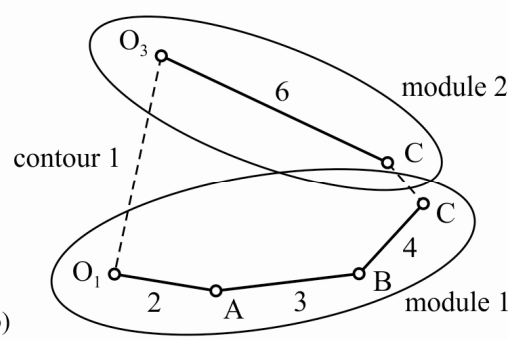

(c)

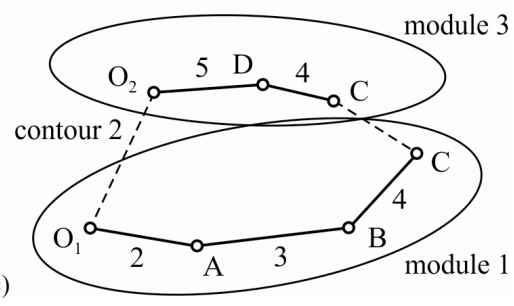

Figure 4. Six-bar mechanism (a) with independent contours and modules (b) and (c) respectively

The same procedure is repeated, but with point $A_{2}$. The first position of point $\mathrm{B}$, marked as $\mathrm{B}_{1}$, is found at the intersection of the symmetry lines. After determining the position of $B_{1}$, the lengths of links $A B=A_{1} B_{1}$ and $\mathrm{BC}=\mathrm{B}_{1} \mathrm{C}_{1}$ also become known. According to the known parameters, the coordinates of point $\mathrm{A}$ in positions 1,2,3,4, are written as follows:

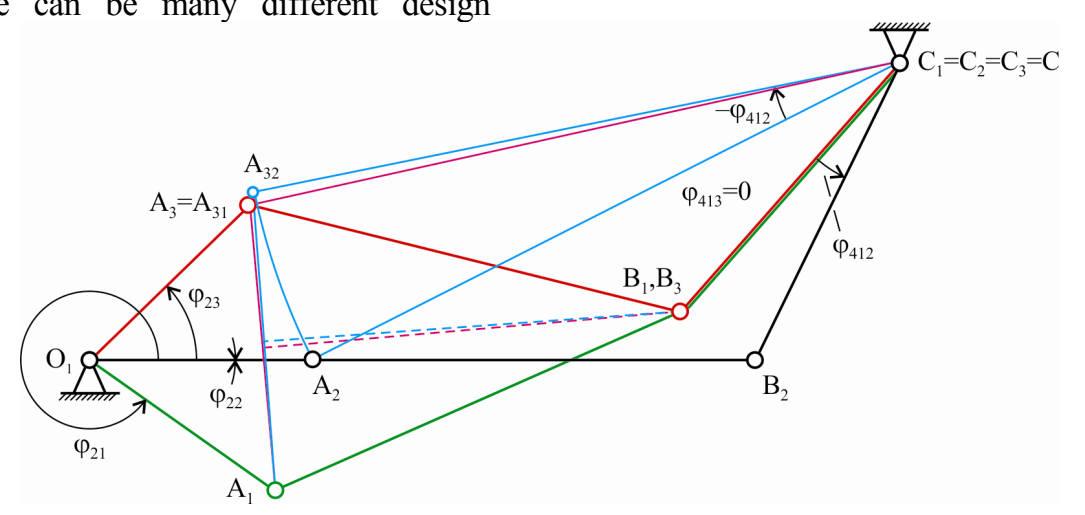

Figure 5. Synthesis of RRR tryad $O_{1} A B C$ 
The same procedure is repeated, but with point $A_{2}$. The first position of point $B$, marked as $B_{1}$, is found at the intersection of the symmetry lines. After determining the position of $B_{1}$, the lengths of links $A B=A_{1} B_{1}$ and $\mathrm{BC}=\mathrm{B}_{1} \mathrm{C}_{1}$ also become known. According to the known parameters, the coordinates of point $\mathrm{A}$ in positions $1,2,3,4$, are written as follows:

$$
\begin{aligned}
& x_{A 1}=\overline{O_{1} A} \cos \left(\varphi_{21}\right) \\
& y_{A 1}=\overline{O_{1} A} \sin \left(\varphi_{21}\right) \\
& x_{A 2}=\overline{O_{1} A} \cos \left(\varphi_{22}\right)=\overline{O_{1} A} \\
& y_{A 2}=\overline{O_{1} A} \sin \left(\varphi_{22}\right)=0 \\
& x_{A 3}=\overline{O_{1} A} \cos \left(\varphi_{23}\right) \\
& y_{A 3}=\overline{O_{1} A} \sin \left(\varphi_{23}\right) \\
& x_{24}=\overline{O_{1} A} \cos \left(\varphi_{24}\right) \\
& y_{24}=\overline{O_{1} A} \sin \left(\varphi_{24}\right)
\end{aligned}
$$

The coordinates of points $\mathrm{A}_{31}$ and $\mathrm{A}_{32}$ are:

$$
\begin{gathered}
x_{A 31}=x_{A 3}, \\
y_{A 31}=y_{A 3} \\
x_{A 32}=x_{A 2} \cos \left(-\varphi_{412}\right)-y_{A 2} \sin \left(-\varphi_{412}\right)- \\
-x_{C} \cos \left(-\varphi_{412}\right)+y_{C} \sin \left(-\varphi_{412}\right) \\
y_{A 32}=x_{A 2} \sin \left(-\varphi_{412}\right)+y_{A 2} \cos \left(-\varphi_{412}\right)- \\
-x_{C} \sin \left(-\varphi_{412}\right)+y_{C} \cos \left(-\varphi_{412}\right)
\end{gathered}
$$

The equations of the symmetry lines of lines $\mathrm{A}_{31} \mathrm{~A}_{1}$ and $\mathrm{A}_{32} \mathrm{~A}_{2}$ are:

$$
\begin{aligned}
y_{A_{31} A_{1}}= & \frac{-1}{\left(\frac{y_{A 3}-y_{A 1}}{x_{A 3}-x_{A 1}}\right)} x+\left(y_{A 1}+\frac{y_{A 3}-y_{A 1}}{2}\right)- \\
& -\frac{-1}{\left(\frac{y_{A 3}-y_{A 1}}{x_{A 3}-x_{A 1}}\right) \cdot\left(x_{A 1}+\frac{x_{A 3}-x_{A 1}}{2}\right)} \\
y_{A_{32} A_{2}}= & \frac{-1}{\left(\frac{y_{A 32}-y_{A 2}}{x_{A 32}-x_{A 2}}\right)} x+\left(y_{A 2}+\frac{y_{A 32}-y_{A 2}}{2}\right)- \\
& -\frac{-1}{\left(\frac{y_{A 32}-y_{A 2}}{x_{A 32}-x_{A 2}}\right)}\left(x_{A 2}+\frac{x_{A 32}-x_{A 2}}{2}\right)
\end{aligned}
$$

At their intersection is point $\mathrm{B}_{1}\left(\mathrm{x}_{\mathrm{B} 1}, \mathrm{y}_{\mathrm{B} 1}\right)$ whose coordinates are found by solving the previous system of equations. These are also the coordinates of point $\mathrm{B}_{3}$ :

$$
\begin{aligned}
& x_{B 3}=x_{B 1} \\
& y_{B 3}=y_{B 1}
\end{aligned}
$$

The length of link $3-$ link $\mathrm{AB}$ is:

$$
\overline{A B}=\sqrt{\left(x_{A 1}-x_{B 1}\right)^{2}-\left(y_{A 1}-y_{B 1}\right)^{2}}
$$

making the coordinates of points $\mathrm{B}_{2}$ and $\mathrm{B}_{4}$ :

$$
\begin{aligned}
& x_{B 2}=x_{A 2}+\overline{A B} \\
& y_{B 2}=y_{A 2}=0 \\
& x_{B 4}=\left(\overline{A B}-\overline{O_{1} A}\right) \cos \left(\varphi_{24}-180^{\circ}\right) \\
& y_{B 4}=\left(\overline{A B}-\overline{O_{1} A}\right) \sin \left(\varphi_{24}-180^{\circ}\right)
\end{aligned}
$$

The length of link $4-$ link $\mathrm{BC}$ is:

$$
\overline{B C}=\sqrt{\left(x_{C}-x_{B 1}\right)^{2}-\left(y_{C}-y_{B 1}\right)^{2}}
$$

\subsection{Module 2 - link $\mathrm{O}_{3} \mathrm{C}$}

In three of the precise positions $1,2,3$, output link 6 is in dwell in the right extreme position and positions $\mathrm{O}_{3} \mathrm{C}_{1}$, $\mathrm{O}_{3} \mathrm{C}_{2}$ and $\mathrm{O}_{3} \mathrm{C}_{3}$ coincide. When the mechanism reaches its left extreme position, output link 6 also reaches its own left extreme position $\mathrm{O}_{3} \mathrm{C}_{4}$. The difference in position angles is the stroke of output link $6-$ angle $\Delta \varphi_{6}$. It is necessary for the synthesis to define one more parameter - design-wise the simplest one is the length of link 6, i.e. the length $\mathrm{O}_{3} \mathrm{C}$. First a circle is drawn with its center in point $\mathrm{B}_{4}$ and its radius equal to $\mathrm{BC}-$ the length of link $\mathrm{BC}$ is constant. Then an isosceles triangle is constructed with its equal length sides being equal to $\mathrm{O}_{3} \mathrm{C}$, and the angle between them to angle $\Delta \varphi_{6}$. Next a circle is constructed with its center in point $\mathrm{C}$ and its radius equal to $a$ - the found length of the isosceles triangle base. Finally, point $\mathrm{C}_{4}$ is found at the intersection of the circles, which is shown in Fig. 6.

The length of base $a$ is:

$$
a=2 \overline{O_{3} C} \sin \left(\Delta \varphi_{6}\right)
$$

The equation of the circle with its center in $\mathrm{B}_{4}$ and its radius equal to $\mathrm{BC}$ is:

$$
\left(x-x_{B 4}\right)^{2}-\left(y-y_{B 4}\right)^{2}=\overline{B C}^{2} .
$$

The equation of the circle with its center in $\mathrm{C}$ and radius $a$ is:

$$
\left(x-x_{C}\right)^{2}-\left(y-y_{C}\right)^{2}=a^{2} .
$$

Point $\mathrm{C}_{4}$ is found at the intersection of these circles. By solving the previous system of equations, the coordinates of point $\mathrm{C}_{4}\left(\mathrm{x}_{\mathrm{C} 4}, \mathrm{y}_{\mathrm{C} 4}\right)$ are found. Notice that there are two solutions to this system of equations and only one should be selected for futher use.

\subsection{Module 3 - $\mathrm{RR}$ dyad $\mathrm{O}_{2} \mathrm{DC}$}

Since positions 1 and 3 coincide, the problem can be viewed as the synthesis of an RR dyad in three precise positions - positions 2,3,4. The precise positions are defined by the positions of length $\mathrm{BC}$, specifically positions $\mathrm{B}_{2} \mathrm{C}_{2}, \mathrm{~B}_{3} \mathrm{C}_{3}$ and $\mathrm{B}_{4} \mathrm{C}_{4}$. Also, to increase the range of solutions, points $\mathrm{B}$ and $\mathrm{C}$ are not considered to be joints of the dyad. To solve this problem, it is necessary to define two more parameters. Due to design requirements - overall dimensions of the mechanism and the available space for it, the most convenient parameters are the coordinates of fixed point $\mathrm{O}_{2}$ that represents the so-called center of the system. The synthesis procedure is shown on Fig. 7. 

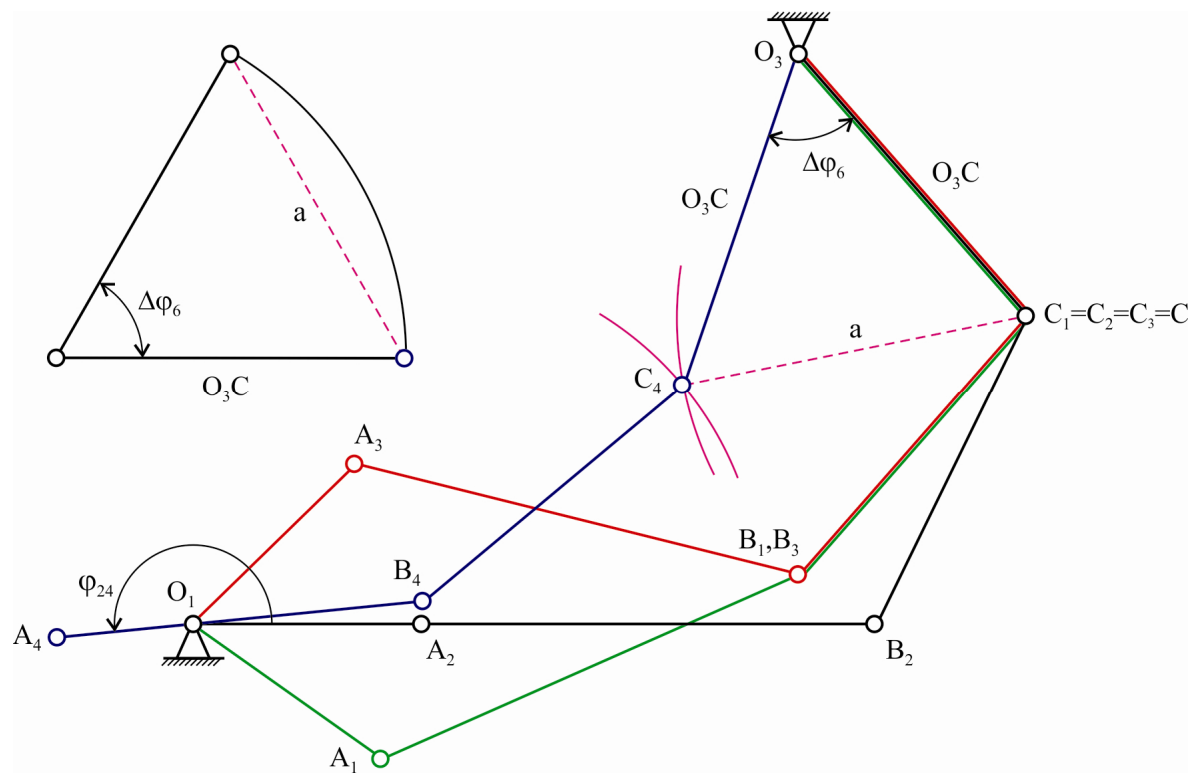

Figure 6. Synthesis of link $\mathrm{O}_{3} \mathrm{C}$

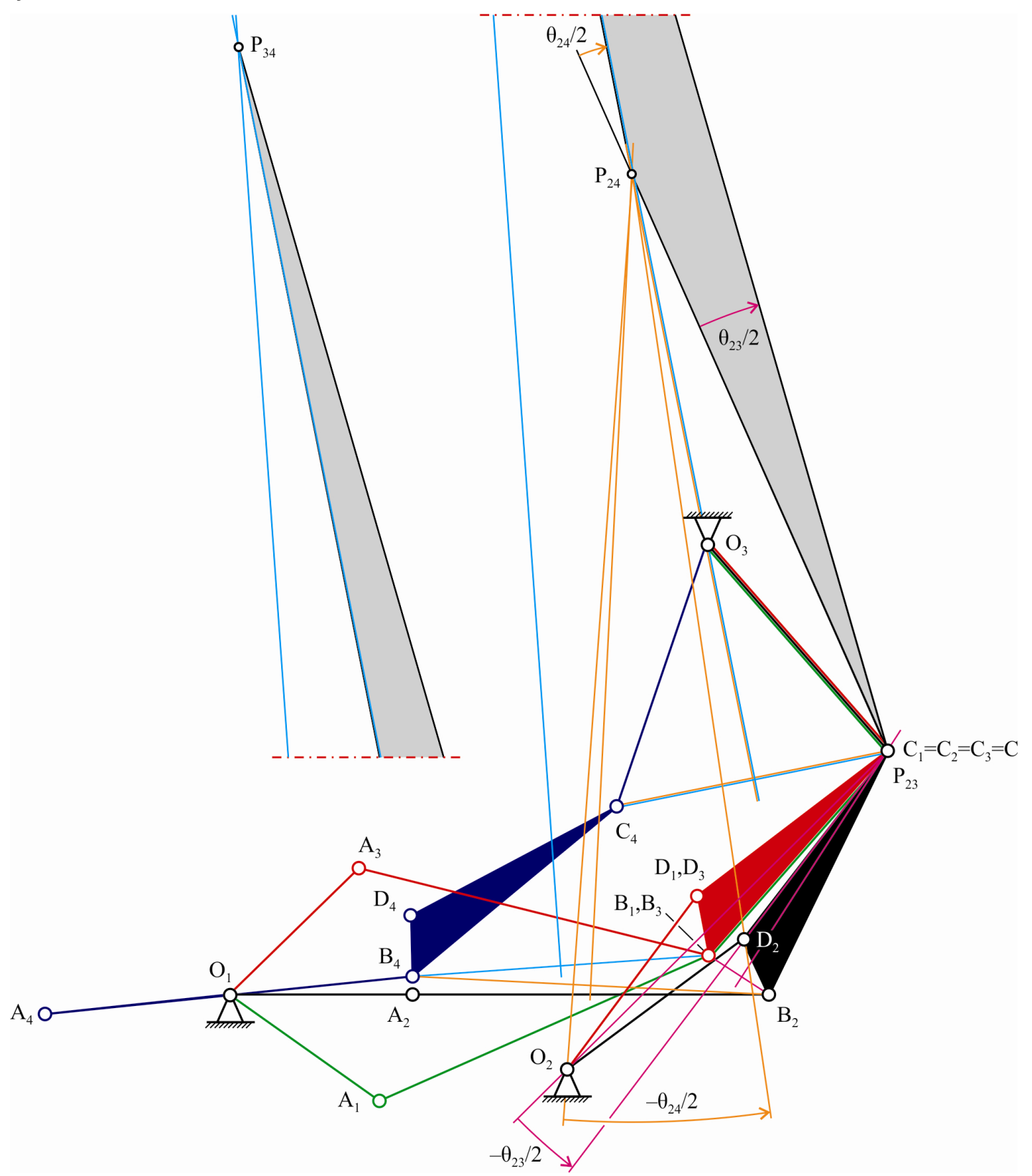

Figure 7. Synthesis of RR dyad $\mathrm{O}_{2} \mathrm{DC}$ 
First the triangle of the finite rotation poles $\mathrm{P}_{23}, \mathrm{P}_{34}, \mathrm{P}_{24}$ is found and the finite rotation angles $\theta_{23} / 2$ and $\theta_{24} / 2$ are defined. A line is constructed through point $\mathrm{P}_{23}$, at the angle $-\theta_{23} / 2$ in relation to line $\mathrm{O}_{2} \mathrm{P}_{23}$, and through point $\mathrm{P}_{24}$, at the angle $-\theta_{24} / 2$ in relation to line $\mathrm{O}_{2} \mathrm{P}_{24}$. At the intersection of these lines is dyad joint - point $\mathrm{D}$ in the first position (point $\mathrm{D}_{1}$ ). After finding $\mathrm{D}_{1}$, and keeping in mind the known position of point $\mathrm{O}_{2}$, the length of link 5 $-\mathrm{O}_{2} \mathrm{D}$ is found. Finally, it is possible to draw the mechanism in every precise position.

The finite rotation angles are:

$$
\begin{aligned}
& \theta_{23}=\arctan \frac{y_{C 3}-y_{B 3}}{x_{C 3}-x_{B 3}}-\arctan \frac{y_{C 2}-y_{B 2}}{x_{C 2}-x_{B 2}} \\
& \theta_{24}=\arctan \frac{y_{C 4}-y_{B 4}}{x_{C 4}-x_{B 4}}-\arctan \frac{y_{C 2}-y_{B 2}}{x_{C 2}-x_{B 2}}
\end{aligned}
$$

The coordinates of the finite rotation poles $\mathrm{P}_{23}$ and $\mathrm{P}_{34}$ are:

$$
\begin{gathered}
x_{P 23}=x_{C}, \\
y_{P 23}=y_{C}, \\
x_{P 24}=k_{1} / k_{2} \\
y_{P 24}=k_{3} / k_{2}
\end{gathered},
$$

where:

$$
\begin{aligned}
& k_{1}=\left|\begin{array}{cc}
x_{B 4}-x_{B 2} \cos \theta_{24}+y_{B 2} \sin \theta_{24} & \sin \theta_{24} \\
y_{B 4}-x_{B 2} \sin \theta_{24}-y_{B 2} \cos \theta_{24} & 1-\cos \theta_{24}
\end{array}\right|, \\
& k_{2}=\left|\begin{array}{cc}
1-\cos \theta_{24} & \sin \theta_{24} \\
-\sin \theta_{24} & 1-\cos \theta_{24}
\end{array}\right|, \\
& k_{3}=\left|\begin{array}{ccc}
1-\cos \theta_{24} & x_{B 4}-x_{B 2} \cos \theta_{24}+y_{B 2} \sin \theta_{24} \\
-\sin \theta_{24} & y_{B 4}-x_{B 2} \sin \theta_{24}-y_{B 2} \cos \theta_{24}
\end{array}\right| .
\end{aligned}
$$

The equation of the line through point $\mathrm{P}_{23}$ at angle $\theta_{23} / 2$ in relation to line $\mathrm{P}_{23} \mathrm{O}_{2}$ is:

$$
\begin{aligned}
y-y_{P 23}= & \tan \left(\arctan \frac{y_{O 2}-y_{P 23}}{x_{O 2}-x_{P 23}}-\frac{\theta_{23}}{2}\right) . \\
& \cdot\left(x-x_{P 23}\right)
\end{aligned}
$$

The equation of the line through point $\mathrm{P}_{24}$ at angle $\theta_{24} / 2$ in relation to line $\mathrm{P}_{24} \mathrm{O}_{2}$ is:

$$
\begin{aligned}
y-y_{p 24}= & \tan \left(\arctan \frac{y_{O 2}-y_{P 24}}{x_{O 2}-x_{P 24}}-\frac{\theta_{24}}{2}\right) . \\
& \cdot\left(x-x_{P 24}\right)
\end{aligned}
$$

At their intersection is point $\mathrm{D}_{2} \quad\left(\mathrm{x}_{\mathrm{D} 2}, \mathrm{y}_{\mathrm{D} 2}\right)$ whose coordinates are found by solving the previous system of equations. The lengths of link $4-\mathrm{BD}$ and link $5-\mathrm{O}_{2} \mathrm{D}$ are:

$$
\begin{aligned}
& \overline{B D}=\sqrt{\left(x_{B 2}-x_{D 2}\right)^{2}-\left(y_{B 2}-y_{D 2}\right)^{2}} \\
& \overline{O_{2} D}=\sqrt{\left(x_{O 2}-x_{D 2}\right)^{2}-\left(y_{) 2 m}-y_{D 2}\right)^{2}}
\end{aligned}
$$

\section{RESULTS}

Using the presented method, the synthesis of a mechanism is performed. For input parameters from
Tables $1 \mathrm{a}$ and $1 \mathrm{~b}$, geometric parameters are found and are presented in Table 2, and based on that, the motion simulation of the mechanism is done - Fig. 8 .

Table 1a. Input parameters

\begin{tabular}{|c|c|c|c|c|c|c|}
\hline $\begin{array}{c}\mathrm{x}_{\mathrm{O} 1} \\
{[\mathrm{~mm}]}\end{array}$ & $\begin{array}{c}\mathrm{y}_{\mathrm{O} 1} \\
{[\mathrm{~mm}]}\end{array}$ & $\begin{array}{c}\mathrm{x}_{\mathrm{C}} \\
{[\mathrm{mm}]}\end{array}$ & $\begin{array}{c}\mathrm{y}_{\mathrm{C}} \\
{[\mathrm{mm}]}\end{array}$ & $\begin{array}{c}\mathrm{O}_{1} \mathrm{~A} \\
{[\mathrm{~mm}]}\end{array}$ & $\begin{array}{c}\varphi_{21} \\
{\left[{ }^{\circ}\right]}\end{array}$ & $\begin{array}{c}\varphi_{22} \\
{\left[{ }^{\circ}\right]}\end{array}$ \\
\hline 0 & 0 & 366 & 136 & 100 & 325 & 0 \\
\hline
\end{tabular}

Table 1b. Input parameters

\begin{tabular}{|c|c|c|c|c|c|c|}
\hline $\begin{array}{c}\mathrm{x}_{\mathrm{O} 2} \\
{[\mathrm{~mm}]}\end{array}$ & $\begin{array}{c}\mathrm{y}_{\mathrm{O} 2} \\
{[\mathrm{~mm}]}\end{array}$ & $\begin{array}{c}\Delta \varphi_{412} \\
{\left[{ }^{\circ}\right]}\end{array}$ & $\begin{array}{c}\Delta \varphi_{6} \\
{\left[{ }^{\circ}\right]}\end{array}$ & $\begin{array}{c}\mathrm{O}_{3} \mathrm{C} \\
{[\mathrm{mm}]}\end{array}$ & $\begin{array}{c}\varphi_{23} \\
{\left[{ }^{\circ}\right]}\end{array}$ & $\begin{array}{c}\varphi_{24} \\
{\left[{ }^{\circ}\right]}\end{array}$ \\
\hline 185 & -40 & 16 & 60 & 154 & 45 & 185 \\
\hline
\end{tabular}

Table 2. Geometric parameters found by synthesis

\begin{tabular}{|c|c|c|c|c|c|c|}
\hline $\begin{array}{c}\mathrm{AB} \\
{[\mathrm{mm}]}\end{array}$ & $\begin{array}{c}\mathrm{BC} \\
{[\mathrm{mm}]}\end{array}$ & $\begin{array}{c}\mathrm{CD} \\
{[\mathrm{mm}]}\end{array}$ & $\begin{array}{c}\mathrm{BD} \\
{[\mathrm{mm}]}\end{array}$ & $\begin{array}{c}\mathrm{O}_{2} \mathrm{D} \\
{[\mathrm{mm}]}\end{array}$ & $\begin{array}{c}\mathrm{x}_{\mathrm{O} 3} \\
{[\mathrm{~mm}]}\end{array}$ & $\begin{array}{c}\mathrm{y}_{\mathrm{O} 3} \\
{[\mathrm{~mm}]}\end{array}$ \\
\hline 199.42 & 151.88 & 134.26 & 33.88 & 120.93 & 265.3 & 252.5 \\
\hline
\end{tabular}

The mechanism is in instantaneous dwell when angle $\varphi_{2}=185^{\circ}$, and in continuous dwell for angle $\varphi_{2}=325^{\circ} \div 45^{\circ}$. The stroke of the output link is $\Delta \varphi_{6}=108.6^{\circ}-\left(49.15^{\circ}+48.15^{\circ}\right) / 2=60^{\circ}$. The dwell is not absolutely accurate. The angle of the output changes during dwell in the range of $-48.15^{\circ}$ to $-49.15^{\circ}$. The median value of the angle equals $-48.65^{\circ}$. To increase the "quality" of the mechanism, i.e. the variation of the output link angle should be reduced as much as possible, which requires further optimization of the system.

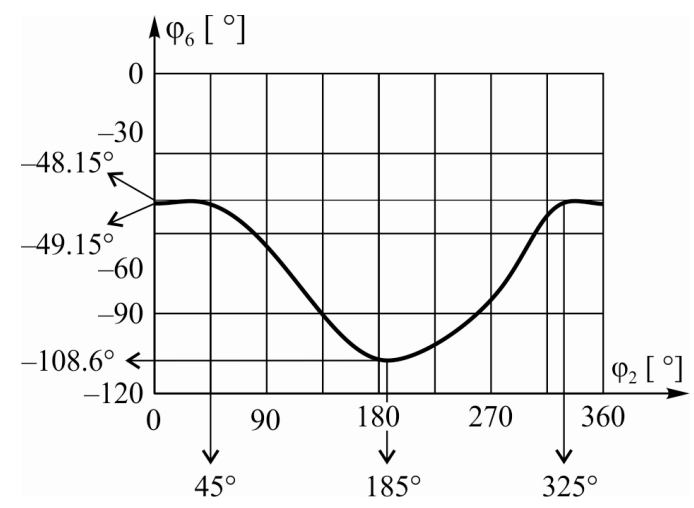

Figure 8. Motion simulation of the mechanism

\section{CONCLUSION}

The paper presents a graphical method for the synthesis of complex structure mechanisms that contain high class structural groups and has an output link with a period of dwell. Graphical methods make the physical design of the mechanism clearly visible, making it easy to avoid issues with singularities and multiple solutions. The procedure is based on the synthesis in extreme positions. This approach simplifies the problem, since the mechanism can now be considered only during the relevant phases of the cycle, instead of during the whole cycle. Mechanisms with one period of dwell were considered, with the motion around a specific extreme position being one of the interest. Further simplification is achieved by considering the mechanism in a finite number of precise positions. The following positions 
were defined as the precise positions - the beginning of the dwell, the extreme position and the end of the dwell, making three precise positions. The other extreme position is adopted as the fourth precise position. The second extreme position is included because the motion from the first to the second extreme position defines the stroke of the output link - the working element. Since this is a complex mechanism, it is necessary to divide it into mutually independent parts structured as open kinematic chains, so-called modules. The methodology of the synthesis of open kinematic chains is very well developed and is based on kinematic geometry principles. In accordance with the solvability and prescribed synthesis requirements, the solving order of the moduls is determined. Analytical equations are formed based on the geometric solution and can be used for further analysis and optimization. As an example, the synthesis of a Stephenson III mechanism containing a 4-bar Assur group was performed. The parameters of the mechanism working cycle were prescribed. The dwell of the output link is not absolute - the angle of the output link changes by $\pm 0.5^{\circ}$, which is still considered acceptably accurate for a wide range of practical applications. To increase the quality of the mechanism dwell, it is possible to optimize the mechanism using the equations formed during the procedure. Future work will see this method expanded to include mechanisms with sliding joints, as well as mechanisms with two required dwell periods per working cycle.

\section{REFERENCES}

[1] Sclater, N. and Chironis, N.P.: Mechanisms and Mechanical Devices Sourcebook, McGraw-Hill, New York, 2007.

[2] Gokarneshan, N., Varadarajan, B. and Senthil Kumar, C.B.: Mechanics and Calculations of Textile Machinery, Woodhead Publishing, New Delhi, 2012.

[3] Norton, R.L.: Design of Machinery: An Introduction to the Synthesis and Analysis of Mechanisms and Machines, McGraw-Hill, New York, 2004.

[4] Wang, Y. and Sun, H.: Computer Aided Analysis of Loom Beating-up Mechanisms, Text. Res. J., Vol. 68, No. 9, pp. 630-634, 1998.

[5] Dorić, J., Klinar, I and Dorić, M.: Constant Volume Combustion Cycle for IC Engines, FME Trans., Vol. 39, No. 3, pp. 97-104, 2011.

[6] Anetor, L., Osakue, E.E., Odetunde, C.: Combustion Dynamics at the Top Dead Center Position of a Spark Ignition Engine, FME Trans., Vol. 45, No. 4, pp. 548-558, 2017.

[7] Jensen, P.W.: Classical and Modern Mechanisms for Engineers and Inventors, Marcel Dekker, Inc., New York, 1991.

[8] Bickford, J.H.: Mechanisms for Intermittent Motion, Industrial Press, Inc., New York, 1972.

[9] Kota, S., Erdman, A.G., Riley, D.R.: Development of Knowledge Base for Designing Linkage-Type
Dwell Mechanisms: Part 1-Theory, J. Mech. Transm., Vol. 109, No. 3, pp. 308-315, 1987.

[10]Kota, S., Erdman, A.G. and Riley, D.R.: Development of Knowledge Base for Designing Linkage-Type Dwell Mechanisms: Part 2Application, J. Mech. Transm., Vol. 109, No. 3, pp. 316-321, 1987.

[11]Kota, S.: Generic Models for Designing Dwell Mechanisms: A Novel Kinematic Design of Stirling Engines as an Example, J. Mech. Des., Vol. 113, No. 4, pp. 446-450, 1991.

[12] Erdman, A.G., Sandor, G.N. and Kota, S.: Mechanism Design: Analysis and Synthesis, Prentice Hall, Inc., Upper Saddle River, 2001.

[13] Cabrera, J.A., Simon, A. and Prado, M.: Optimal Synthesis of Mechanisms with Genetic Algorithms, Mech. Mach. Theory, Vol. 37, No. 10, pp. 1165$1177,2002$.

[14] Tso, P.-L. and Wang, W.-S.: Designing Ternary Link for Stephenson III Six-bar Mechanical Presses, in: Proc. of the $14^{\text {th }}$ IFToMM World Congress,. 25-30.10.2015, Taipei, pp. 595-598.

[15] Todorov, T.S.: Synthesis of Watt's Six-Link Mechanism for Manipulation Action in Relative Space, Mech. Mach. Theory, Vol. 32, No. 5, pp. 559-568, 1997.

[16] Soh, G.S. and McCarthy, J.M.: The Synthesis of Six-Bar Linkages as Constrained Planar 3R Chains, Mech. Mach. Theory, Vol, 43, No. 2, pp. 160-170, 2008.

[17] Shiakolas, P.S., Koladiya, D. and Kebrle, J.: On the Optimum Synthesis of Six-Bar Linkages using Differential Evolution and the Geometric Centroid of Precision Positions Technique, Mech. Mach. Theory, Vol. 40, No. 3, pp. 319-335, 2005.

[18] Yu, H., Wang, Z., Tang, D. and Li, J.: Study on Numerical Comparison Method for Planar Six-bar Dwell Mechanism Synthesis, in: Proc. of the $11^{\text {th }}$ IFToMM World Congress, 18-21.08.2003, Tianjin, pp. 1-5.

[19] Mariappan, J. and Krishnamurty, S.: A Generalized Exact Gradient Method for Mechanism Synthesis, Mech. Mach. Theory, Vol. 31, No. 4, pp. 413-421, 1996.

[20] Jagannath M. and Bandyopadhyay, S.: A New Approach Towards the Synthesis of Six-Bar Double Dwell Mechanisms, in: Kecskeméthy A. and Müller A. (Eds.) Computational Kinematics, Springer, Berlin, pp. 209-216, 2009.

[21]Pennock, G.R. and Israr, A. Kinematic Analysis and Synthesis of an Adjustable Six-Bar Linkage, Mech. Mach. Theory, Vol. 44, No. 2, pp. 306-323, 2009.

[22] Čavić, M., Zlokolica, M. and Kostić, M.: About Analytical Synthesis of the Mechanisms with High Class Kinematic Group, in: Proc. of the $1^{\text {st }}$ International Congress of Serbian Society of Mechanics, 10-13.04.2007, Kopaonik, pp. 125-130. 
[23] Chase, T.R., Erdman, A.G. and Riley, D.R.: Triad Synthesis for up to Five Design Positions with Application to the Design of Arbitrary Planar Mechanisms, J. Mech. Transm., Vol. 109, No. 4, pp. 426-434, 1987.

[24] Subbian T., Flugrad, D.R.: Five Position Triad Synthesis with Applications to Four-and Six-Bar Mechanisms, J. Mech. Des., Vol. 115, No. 2, pp. 262-268, 1993.

\section{ГРАФИЧКА СИНТЕЗА ШЕСТОЧЛАНОГ ПОЛУЖНОГ МЕХАНИЗМА СА ПРЕКИДНИМ КРЕТАњЕМ}

М. Чавић, М. Пенчић, М. Рацков, Ј. Дорић, З. Лу

Механизми машина чије се операције понављају имају значајну примену у процесној индустрији.
Такве машине захтевају посебан радни циклус при чему излазни члан радног механизма током једног дела операције мирује, а улазни члан се непрекидно креће. Рад приказује графичку синтезу шесточланог полужног механизма сложене структуре који садржи структурне групе виших класа. Поступак је заснован на синтези у екстремним положајима механизма. На тај начин се проблем поједностављује, па се механизам може посматрати у коначном броју прецизних положаја. У основи поступка су једноставне, јасно видљиве и разумљиве геометријске конструкције. Упоредо су формиране једначине погодне за даљу анализу и оптимизацију. Излазни члан механизма добијен поступком синтезе има варијације - угао излазног члана се током периода мировања мења $\pm 0.5^{\circ}$, што је довољна тачност за широк спектар практичних реализација. 